\title{
Deacons and Diakonia in Early Christianity
}

\author{
The First Two Centuries \\ Ed. by Bart J. Koet, Edwina Murphy, and Esko Ryökäs
}

[Diakone und Diakonia im frühen Christentum. Die ersten beiden Jahrhunderte.]

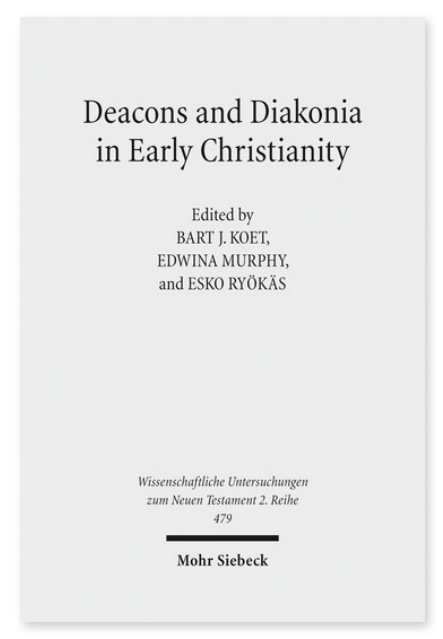

2018. XIV, 327 pages. WUNT II 479

ISBN 978-3-16-156646-2 sewn paper $104,00 €$ ISBN 978-3-16-156647-9 eBook PDF $104,00 €$
Published in English.

In German-speaking countries, the role of the diaconate has been strongly influenced by nineteenth-century ideas of diakonia as service towards the poor. As important as the social initiatives stemming from this perspective have been, in order to correctly understand deacons and diakonia in the early church, we must go back to the sources. For this volume, focused on the first two centuries of Christianity, scholars from a range of backgrounds consider the use of diakonos and related words in the New Testament and extra-biblical sources, both Christian and otherwise. These texts reveal what deacons actually did, helping us to understand the past and giving guidance for the present, particularly in ecumenical discussions concerning the ministry.

\section{Survey of contents}

Munib Younan: Foreword

\section{A) Introduction}

Bart J. Koet/Edwina Murphy/Esko Ryökäs: Assessing the Role and Function of an Assistant: The Deacon in the First Two Centuries of Christianity

\section{B) Biblical Sources}

Peter-Ben Smit: Exegetical Notes on Mark 10:42-45: Who Serves Whom? - John N. Collins: The Rhetorical Value of $\Delta$ takov- in Matthew 25:44 - Bart J. Koet: Luke 10:38-42 and Acts 6:1-7: a Lukan Diptych on $\Delta$ เakoví $\alpha$ - Bart J. Koet: Like a Royal Wedding. On the Significance of Diakonos in John 2:1-11 - Joke H. A. Brinkhof: Philip, One of the Seven in Acts (6:1-6; 8:4-40; 21:8) Margaret Mowczko: What did Phoebe's Position and Ministry as $\Delta$ lókovoৎ of the Church at Cenchrea Involve? - Anni Hentschel: Paul's Apostleship and the Concept of $\Delta$ lakovía in 2 Corinthians - Lauri Thurén: Divine Headhunting? The Function of the Qualifications of Deacons in 1 Tim 3:8-13

\section{C) The Earliest Christian (Extra-Biblical) Sources}

John Granger Cook: Pliny's Tortured Ministrae : Female Deacons in the Ancient Church? - BartJ. Koet: The Bishop and his Deacons. Ignatius of Antioch's View on Ministry: Two-fold or Three-fold? - John N. Collins: $\Delta$ เakov- and Deacons in Clement of Alexandria - Bart J. Koet: Isaiah 60:17 as a Key for Understanding the Two-fold Ministry of 'Eпı бкómol and $\Delta$ lókovol according to First Clement (1 Clem. 42:5) - Mark Grundeken: What Do »Deacons« Do in the Shepherd of Hermas? - Clayton N. Jefford: Understanding the Concept of Deacon in the Didache - Paul Foster: Deacons ( $\Delta$ เókovol) and Dı $\alpha$ koví $\alpha$ in the Writings of Justin and Irenaeus - Serafim Seppälä: Deacons in Acts of Thomas and Related Early Syriac Literature - Anni Maria Laato: Tertullian and the Deacons - BartJ. Koet: Dreaming about Deacons in the Passio Perpetuae - Anssi Voitila: Deacons in the Texts Contemporary with the New Testament (Philo of Alexandria and Josephus)

Bart J. Koet Born 1955; Professor of New Testament Studies and Early Christian Literature, and Dean of Research at the Tilburg School of Catholic Theology.

Edwina Murphy Born 1970; Lecturer in Church History at Morling College (Australian College of Theology and University of Divinity) in Sydney, Australia.

Esko Ryökäs Born 1953; Adjunct Professor in Systematic Theology at University of Eastern Finland in Joensuu and docent in Practical Theology at Åbo Akademi University.

\section{Order now:}

https://www.mohrsiebeck.com/en/book/deacons-and-diakonia-in-early-christianity-9783161566462?no_cache=1 order@mohrsiebeck.com Phone: +49 (0)7071-923-17 Fax: +49 (0)7071-51104 